\title{
Development of Central Nervous System in Scuttle Fly
}

\author{
Ho-Hyun Park ${ }^{1}$, Mi-Suk Park ${ }^{2}$, Kil-Ju Na ${ }^{3}$ \\ ${ }^{1}$ Department of Biomedical Laboratory Science, Mokpo Science University, Mokpo, Korea \\ ${ }^{2}$ Department of Medical Laboratory Science, Gimhae College, Gimhae, Korea \\ ${ }^{3}$ Department of Radiology Science, Mokpo Science University, Mokpo, Korea
}

\section{Scuttle Fly에서 중추신경계 발달 연구}

\author{
박호현 ${ }^{1}$, 박미숙 $^{2}$, 나길주 ${ }^{3}$ \\ ${ }^{1}$ 목포과학대학교 임상병리학과, ${ }^{2}$ 김해대학교 임상병리학과, ${ }^{3}$ 목포과학대학교 방사선학과
}

\begin{abstract}
The scuttle fly central nervous system (CNS) is unobservable during egg and larvae instar stage 1. During days 2 3 of larvae instar stage 2, the left and right hemisphere of the brain can be observed. Below the brain, the subesophageal ganglion (SOG) connects to the ventral nerve cord (VNC). During days 3 5 of larvae instar stage 3 , the CNS enlarged slightly with no other changes. During days $1 \sim 3$ of the pupal stage the CNS moved to the head with no distinguishable changes from the previous stage. During days $4 \sim 6$ of the pupal stage, the left and right hemisphere of the brain had fused into one mass and the optic lobe $(\mathrm{OL})$ located on the side of the brain completed its development. During days $7 \sim 9$ of the pupal stage, the OL began to show eyeball pigment. The SOG was connected to the brain and the VNC began to separate, which was accompanied by an increase in nerve fibers. During days 10 12 of the pupal stage, the brain of the CNS and VNC was clearly distinguished and the brown pigmentation of OL became darker. During days 13 15 days of the pupal stage, the separated brain and VNC became connected by thin nerve fiber. The VNC began to separate into two with a greater increase in nerve fibers. The adult fly showed similar features to the previous stage, but the brain was located in the head and the VNC in the chest.
\end{abstract}

Key words: Brain, Central nervous system, Megaselia scalaris, Scuttle fly, Ventral nerve cord

This is an Open Access article distributed under the terms of the Creative Commons Attribution Non-Commercial License (http://creativecommons.org/licenses/by-nc/4.0) which permits unrestricted non-commercial use, distribution, and reproduction in any medium, provided the original work is properly cited.

Copyright ( 2018 The Korean Society for Clinical Laboratory Science. All rights reserved.

\section{(1)}


결합되어 있으며, 뇌 및 복신경색 조직에는 신경섬유가 많이 신 장되어 있다고 하였다[5-7](Figure 2A). 번데기 시기의 중추신 경계는 애벌레 시기와 다르게 바로 앞부분에 위치해 있고 초기 에는 제 3 령 애벌레와 유사한 모양과 특징을 갖고 있지만 변태 가 진행됨에 따라 식도하신경절은 뇌 조직으로 연속되어 있고, 후기에는 복신경색 조직과 분리가 되어 신경섬유와 조직에 의 해 점차 가늘어 진다(Figure $2 \mathrm{~B}$ ). 성충 시기에는 머리와 가슴, 배 부분으로 완전히 나누어지는데 중추신경계의 뇌는 머리 부분 에, 복신경색은 가슴 부분에 위치해 있다[8-10]. 뇌 조직에 양쪽 시엽과 수질(medulla) 부분이 완성되어 안구가 형성되고, 복신 경색 조직도 뇌 조직의 식도하신경절과 약간의 신경섬유와 조 직에 의해서 겨우 연결되어 분리되어 있으며, 또한 위와아래 부 분으로 조직이 두 개로 분리되는 변화가 이루어진다고 하였다 [5, 11-13](Figure 2C).

그러므로 본 연구에서는 아직까지 순간적인 정지와 질주를 반복하는 독특한 행동의 특성을 보이는 scuttle fly 중추신경계 의 발달에 대한 연구가 많이 이루어지지 않았기 때문에 기존의 연구를 토대로 확인하고자 하였다.

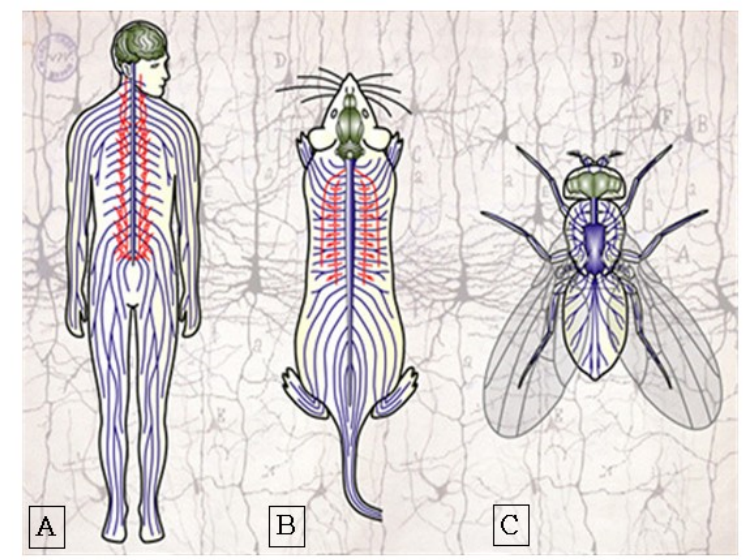

Figure 1. The nervous systems of human, mouse and scuttle fly. (A) human, (B) mouse, (C) scuttle fly.

\section{재료 및 방법}

\section{1. 사육}

실험에 이용한 scuttle fly는 Megaselia scalaris라는 학명을 가진 파리이며, 초파리와 동일한 먹이를 이용하여 사육하였다. 사육을 위한 배지는 증류수 $250 \mathrm{~mL}$ 에 dextrose $16 \mathrm{~g}$, yeast flakes $6.5 \mathrm{~g}$, cornmeal $20 \mathrm{~g}$, agar $2.25 \mathrm{~g}$ 을 교반기를 이용하여 혼합하고 전자렌지에서 10 분 정도 꼻어 넘치지 않을 정도로 가 열하였다. 그리고 methylparaben $6.25 \mathrm{~mL}$ 를 천천히 떨어뜨려 서 혼합하고 배지 통에 부은 후 식힌 다음 성충을 이동시켜 사육 을 하였다. 사육은 1 주일 간격으로 다른 배지에 성충을 옮겨서 지속적으로 시행하였다. 제작된 사육 배지는 $4^{\circ} \mathrm{C}$ 냉장고에 보 관하였으며 사용 전 실온에 맞추기 위해 미리 꺼내 놓은 후 사용 하였다[14].

\section{2. 중추신경계 채취}

Scuttle fly을 애벌레(larvae) 시기 2령 2 3일, 3령 3 5일과 번데기(pupae) 시기 1 3일, 4 6일, 7 9일, 10 12일, 13 15 일 그리고 성충(adult) 시기별로 각각 5개 이상의 개체를 사 용하였다. $0.1 \%$ tween 20이 포함된 중성인산완충액(phosphate buffer solution, $\mathrm{pH}$ 7.0, PBS)이 채워져 있는 홈이 파인 슬라이 드에 개체를 담근 상태로 입체현미경(stereomicroscope) 상에 서 가늘고 정밀한 핀셋을 이용하여 애벌레, 번데기, 성충의 껍질 부분을 박리하면서 채취하였고, 중추신경계 조직인 뇌와 복신 경색 조직을 적출하여 그 형태를 관찰하였다. 발생 단계별로 채 취된 중추신경계 조직을 $4 \%$ paraformaldehyde 용액에 넣은 후 $4^{\circ} \mathrm{C}$ 냉장고에 1 시간 이상 고정하여 보관하였다.

\section{결 과}

Scuttle fly의 발생 단계별로 중추신경계(central nervous
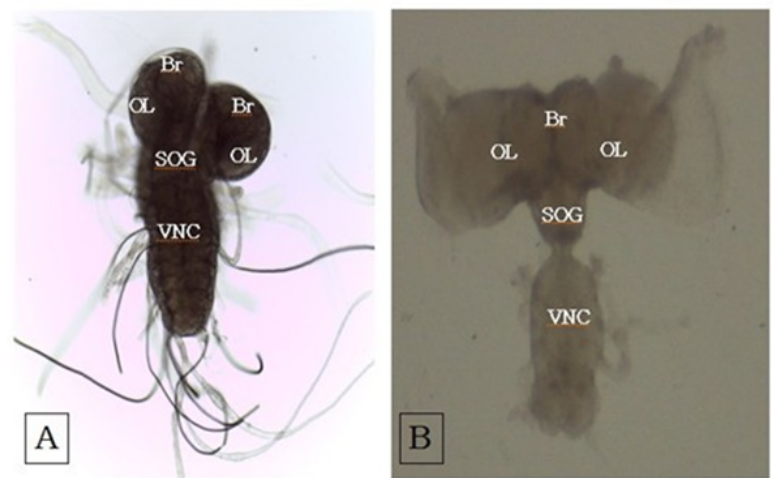

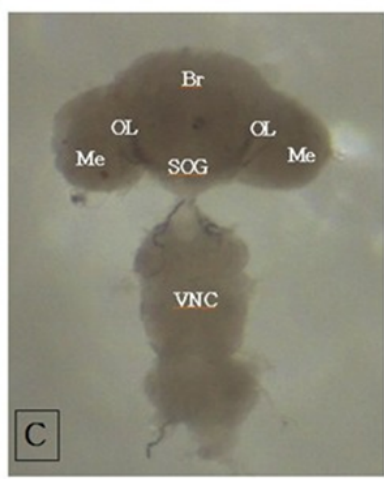

Figure 2. Morphological changes of CNS in D. melanogaster through metamorphic development. (A) larval stage, (B) pupal stage (10 days), (C) adult fly. Abbreviations: $\mathrm{Br}$, brain; VNC, ventral nerve cord; OL, optic lobe; SOG, subesophageal ganglion; Me, Medulla. 
system, CNS) 조직을 채집하여 입체현미경 상에서 형태적 변 화 등을 관찰하였다. 알(egg) 시기와 애벌레 1령 시기는 애벌레 의 크기가 너무 작아서 중추신경계를 분리하기 어려우므로 애 벌레 2령 시기부터 성충까지를 대상으로 중추신경계를 추출 하 였다.

애벌레 2 령 시기는 뇌가 머리 앞쪽에서 다섯 번째 체절 부분 에 위치해 있었으며 침샘 바로 뒤쪽에 위치하고 있었다. 중추신 경계 조직의 구조는 윗부분의 뇌가 좌측과 우측으로 분리되어 있었고 가장자리에는 아직 발생되지 않은 시엽(optic lobe, OL) 해당 부위가 있었다. 그리고 아래 부분에는 하나의 복신경색과 결합되어 있는 식도하신경절이 뇌와 연결되어 있었고 복신경색 은 “ㄴ"자로 구부러져 있는 모양으로 관찰되었다. 이 시기에는 중추신경계 조직이 크기가 작고, 뇌 조직에서 빠져 나온 신경섬 유가 거의 없었으며 복신경색 조직에서는 약간의 신경섬유가 발견 되었다(Figure $3 \mathrm{~A}$ ). 애벌레 3 령 시기에는 애벌레 2령 시기 에 비해 중추신경계가 약간 더 커져 있는 것을 제외하고는 모양 과 구조가 동일한 특성을 가지고 있었다. 하지만 뇌와 복신경색 조직에는 애벌레 2령 시기에 비해서 아주 많은 신경섬유가 발달 되어 있었다(Figure 3B).

번데기가 되면 중추신경계 조직이 애벌레 2령, 3령 시기와다 르게 맨 앞쪽 머리에 가깝게 위치하고 있었고, 1 15일의 생육 기간에 따라 형태가 크게 변화되는 특징을 볼 수가 있었다. 번데 기 1 3일 시기에서의 중추신경계 조직은 애벌레 3령 시기의 모양과 형태가 거의 비슷하였다. 아직까지는 좌측과 우측으로

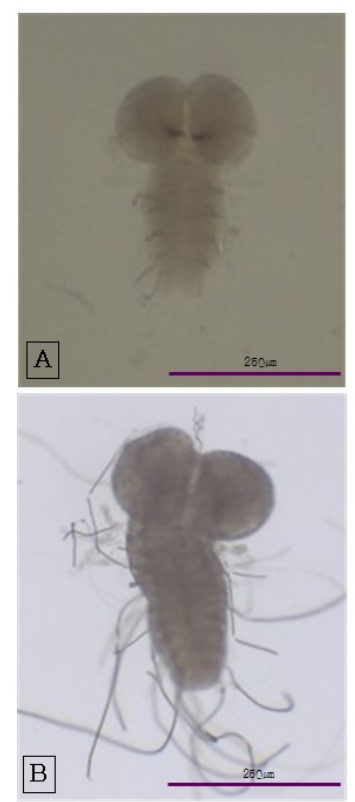

Figure 3. Morphological changes of CNS during larval development. stereomicroscope, $\times 40$. (A) 2-nd instar, (B) 3-rd instar.
뇌 조직이 분리가 되어 있었고, 식도하신경절이 복신경색 조직 과 결합되어 뇌 조직과 연결이 되어 있는 특성을 보이고 있었다. 하지만 크기가 약간 커져 있는 것과 구부러져 있던 복신경색 조 직이 펴져 있는 것을 관찰하였고, 뇌와 복신경색 조직의 신경섬 유는 번데기가 되자마자 거의 사라졌다. 그리고 좌측과 우측 뇌 조직 가장자리 쪽의 시엽 조직이 3일째부터 점차 발생이 되기 시작하였다(Figure 4A, 4B). 번데기 4 6일 시기에는 중추신경 계 조직이 1 3일 시기보다 크기가 약간 더 커져 있고, 좌측과 우측으로 분리되어 있었던 뇌 조직은 점점 밀착 되어 합쳐져 있 었으며 가장자리에 자리 잡은 시엽 조직도 점점 발생하여 완성 된 형태로 만들어지는 것을 관찰 하였다. 아직까지 복신경색 조 직은 식도하신경절과 결합되어서 뇌 조직과 연결이 되어 있었 다. 신경섬유는 1 3일 시기에 제거 되었던 것이 다시 뇌 조직에 뭉쳐서 점점 증가되고 있는 것이 관찰되었고, 복신경색 조직의 신경섬유는 거의 존재하지 않았다(Figure 4C). 번데기 7 9일 시기에도 중추신경계 조직이 4 6일 시기보다 크기가 약간 더 커져 있었고, 뇌 조직은 가장자리의 시엽 조직이 점차 완전한 형 태를 갖추고 수질도 함께 발생되고 있었으며 가장자리에는 약 한 갈색의 안구 색소가 보이기 시작했다. 그리고 식도하신경절 이 뇌 조직과 결합되면서 복신경색 조직과 분리가 되기 시작하 는 것도 볼 수가 있었다. 또한 신경섬유도 뇌 조직에서 지속적으 로 증가되는 것을 관찰 하였다(Figure 4D). 번데기 10 12일 시 기에는 중추신경계의 뇌와 복신경색 조직과의 경계가 뇌 쪽에

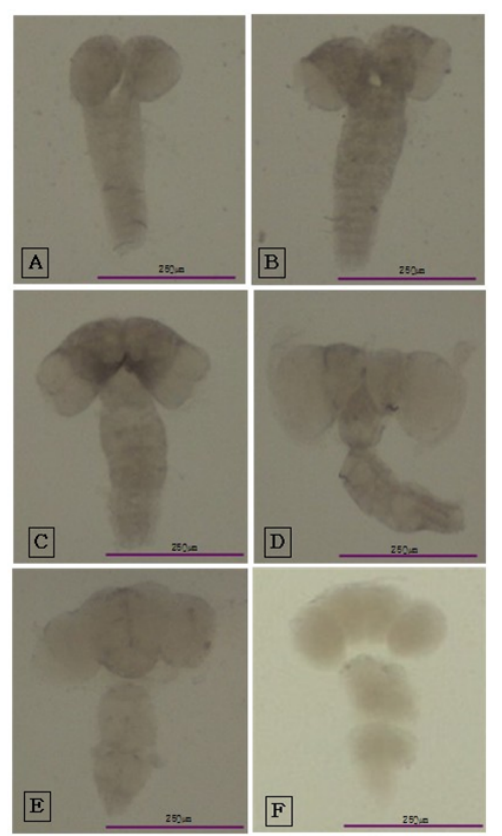

Figure 4. Morphological changes of CNS during pupal development. stereomicroscope, $\times 40$. (A) 1 day, (B) 3 days, (C) 4 6 days, (D) $7 \sim 9$ days, (E) 10 12 days, (F) 13 15 days. 
위치해 있는 식도하신경절을 경계로 뚜렷하게 분리되면서 점점 가느다란 조직 형태로 분화되기 시작하였다. 뇌 조직의 가장자 리에 존재하는 시엽 조직의 수질이 거의 완성되었고 여기에 안 구 색소도 갈색으로 뚜렷이 관찰 되었다(Figure 4E). 번데기 13 15일 시기에는 뇌 조직 밑의 식도하신경절을 기준으로 복신 경색 조직이 가느다란 신경섬유와 조직에 의해 겨우 연결되어 있는 것을 볼 수 있었다. 또한 뇌 조직에 많은 신경섬유가 생성되 어 있었으며, 복신경색 조직도 위와 아래 두 개의 조직으로 약간 씩 분리되기 시작하는 것을 볼수 있었다. 또한 완전한 구조로 발 생된 시엽과 수질 조직의 가장자리에서 안구 색소가 완전하게 생성되어 더욱더 황갈색으로 변하므로, 성충의 중추신경계의 형태와 거의 유사한 것을 관찰 할 수 있었다(Figure $4 \mathrm{~F}$ ).

번데기 13 15일 시기에 완성된 성충의 중추신경계 조직은 머리 부분에 뇌조직, 가슴 앞쪽 부분에 복신경색 조직이 위치해 있으며, 식도하신경절은 번데기 시기 말까지 돌출되어 보였던 것이 뇌 조직과 일체가 되어 구분이 불분명해지고 가느다란 신 경섬유와 조직 등에 의해 간신히 연결이 되어 복신경색 조직과 분리되어 있는 것을 볼수 있다. 안구 조직은 좌측과 우측시엽과 수질의 가장자리 양쪽 끝에는 진한 흑갈색의 색소가 완성되어 있고, 뇌 조직에는 많은 신경섬유가 발달해 있는 것을 관찰하였 다. 또한 복신경색 조직도 위와 아래로 완전히 분리가 되어서 가 느다란 섬유와 조직으로 연결되어 분리되어 있는 것을 관찰할 수 있었다(Figure 5).

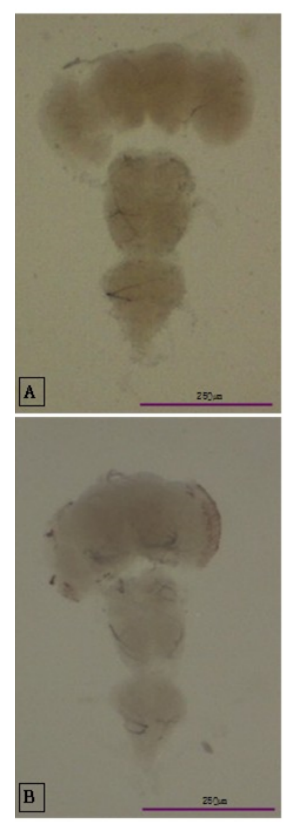

Figure 5. Morphology of fully developed CNS in adult scuttle fly. Stereomicroscope, $\times 40$. (A, B) adult fly.

\section{고 찰}

Scuttle fly의 행동 특성을 이해하기 위해서 이 파리의 중추신 경계의 발달 과정을 살펴보는 것은 당연히 필요한 과정이다. Scuttle fly의 발생 단계별로 진행됨에 따라 중추신경계 조직의 위치는 애벌레 시기에는 머리 앞쪽에서 조금 떨어진 곳에 위치 해 있었고, 번데기와 성충 시기에는 머리 앞쪽에 위치해 있는 것 을 확인 하였다[14]. 또한 발생이 진행됨에 따라 중추신경계의 크기가 점점 커지는 것을 확인 하였다. 애벌레 시기에는 뇌와 복 신경색 조직이 식도하신경절에 의해 연결이 되어 있었고[6], 번 데기 시기 초기에는 애벌레 시기의 형태와같지만 점점 후기 또 는 성충으로 진행될수록 뇌에 연결 되어있는 식도하신경절을 기준으로 해서 복신경색 조직이 약간의 신경섬유와 조직에 의 해서 가늘게 분리되는 특징을 확인 하였다.

그리고 뇌 조직은 좌측과 우측으로 분리가 되어 있는 애벌레 시기에서 번데기, 성충 시기가 되면서 점점 하나로 밀착이 되어 발달 되었고, 뇌 조직 가장자리의 시엽 조직도 애벌레에서 발달 이 되지 않았지만 번데기 초기부터 발달이 되어 성충이 되기 전 에 완성이 되는 것을 확인하였다. 아울러 번데기 후기에 시엽 수 질 가장자리에 안구 색소가 만들어지고 성충이 되면서 안구가 완성되는 것을 확인 하였다[15, 16].

애벌레 시기의 복신경색에 많은 신경섬유가 존재하지만 번 데기와 성충 시기로 갈수록 신경섬유가 줄어들고 오히려 뇌 조 직에서 신경섬유가 많은 증가를 보이고 있는 것을 알 수 있었다. 그리고 복신경색 조직은 번데기 후기에 위와 아래의 조직으로 분리되어 성충이 되면서 완전히 분리되는 특징 등을 확인하였 다[5].

\section{요 약}

Scuttle fly의 중추신경계는 알 시기와 애벌레 1 령 시기는 애 벌레의 크기가 너무 작아서 중추신경계를 분리하기 곤란하여 채취하지 못하여 형태를 관찰할 수 없었고, 애벌레 시기 2령 (instar) 2 3일은 윗부분의 뇌가 좌측과 우측으로 분리되어 있 었고 아래 부분에는 식도하신경절에 의해 복신경색이 “ㄴ"자 모양으로 연결되어 있었다. 애벌레 3령 3 5일은 2령에 비해 중 추신경계가 약간 커져 있는 것을 제외하고는 동일한 특성을 가 지고 있었다. 번데기 시기에는 중추신경계가 앞쪽 머리에 위치 하고 있었고, 번데기 1 3일에는 애벌레 3령 시기의 모양과 형 태가 거의 비슷했으며, 번데기 4 6일에는 좌측과 우측으로 분 리되어 있었던 뇌 조직이 점점 밀착되어 합쳐져 있었으며 가장 
자리에 자리 잡은 시엽도 점점 발생하여 완성된 형태로 만들어 지고 있었다. 번데기 7 9일에는 시엽 가장자리에 안구 색소 (eyeball pigment)가 관찰되었고식도하신경절이 뇌조직과 결 합되면서 복신경색 조직과 분리되기 시작하고 신경섬유(nerve fiber)도 많이 증가되고 있었다. 번데기 10 12일에는 중추신 경계의 뇌와 복신경색이 뚜렷하게 분리되었고 시엽의 안구 색 소도 진한 갈색으로 뚜렷이 관찰되었다. 번데기 13 15일에는 분리된 뇌와 복신경색 조직이 가느다란 신경섬유에 의해 겨우 연결되어 있었고 복신경색 조직도 위와 아래로 두 개로 분리되 기 시작하였고 무수히 많은 신경섬유가 생성되어 있었다. 그리 고 성충 시기에는 번데기 13 15일 시기와 거의 비슷한 특징을 가지고 있고, 특히 중추신경계 조직인 머리 부분의 뇌 조직과 가 슴 앞쪽 부분의 복신경색 조직이 위치해 있는 것을 관찰하였다.

\section{Acknowledgements: None \\ Conflict of interest: None}

\section{REFERENCES}

1. Choi YJ, Lee G, Park JH. Programmed cell death mechanisms of identifiable peptidergic neurons in Drosophila melanogaster. Development. 2006;133:2223-2232.

2. Choi YJ, Lee G, Hall JC, Park JH. Comparative analysis of Corazonin-encoding genes (Crz's) in Drosophila species and functional insights into $\mathrm{Crz}$-expressing neurons. J Comp Neurol. 2005;482:372-385.

3. Lee G, Kim KM, Kikuno K, Wang Z, Choi YJ, Park JH. Developmental regulation and functions of the expression of the neuropeptide corazonin in Drosophila melanogaster. Cell Tissue Res. 2008;331:659-673.

4. Lee G, Wang Z, Sehgal R, Chen CH, Kikuno K, Hay B, et al. Drosophila caspases involved in developmentally regulated programmed cell death of peptidergic neurons during early metamorphosis. J Comp Neurol. 2011;519:34-48.

5. Sun B, Xu P, Salvaterra PM. Dynamic visualization of nervous system in live Drosophila. Neurobiology Proc Natl Acad Sci. 1999;96:10438-10443.

6. Jeibmann A, Paulus W. Drosophila melanogaster as a model organism of brain diseases. Int J Mol Sci. 2009;10:407-440.

7. Hartenstein V. Atlas of drosophila development. 1 ed. New York: Cold Spring Harbor Laboratory Press; 1993. p1-57.

8. Roller L, Tanaka S, Kimura K, Satake H, Tanaka Y. Molecular cloning of $\left[\mathrm{Thr}^{4}, \mathrm{His}^{7}\right]$-corazonin (Apime-corazonin) and its distribution in the central nervous system of the honey bee Apis mellifera (Hymenoptera: Apidae). Appl Entomol Zool. 2006;41: 331-338.

9. Roller L, Tanaka Y, Tanaka S. Corazonin and corazonin-like substances in the central nervous system of the Pterygote and Apterygote insects. Cell Tissue Tes. 2003;312:393-406.

10. Verleyen P, Baggerman G, Mertens I, Vandersmissen T, Huybrechts J, Van Lommel A, et al. Cloning and characterization of a third isoform of corazonin in the honey bee Apis mellifera. Peptides. 2006;27:493-499.

11. Tanaka S. Endocrine mechanism of controlling body-color polymorphism in locusts. Arch Insect Biochem Physiol. 2001;47:139-149.

12. Tanaka S, Zhu DH, Hoste B, Breuer M. The dark-color inducing neuropoptide, His7-corazonin, causes a shift in morphometric characteristics towards the gregarious phase in isolated-reared (solitarious) Locusta migratoria. J Insect physiol. 2002;48:10651074.

13. Tawfik AI, Tanaka S, De Loof A, Schoofs L, Baggerman G, Waelkens E, et al. Identification of the gregarization-associated dark-pigmentotropin in locusts through an albino mutant. Proc Natl Acad Sci. 1999;96:7083-7087.

14. Park HH. The development stages of scuttle fly. Biomedical Science Letters. 2018;24:125-129.

15. Sweeney ST, Hidalgo A, de Belle JS, Keshishian H. Dissection of adult Drosophila brains. Cold Spring Harb Protoc. 2011;12: 1472-1474.

16. Williamson WR, Hiesinger PR. Preparation of developing and adult Drsophila brains and retianse for live imaging. J Vis Exp. 2010;37:1936. 